\title{
Analisis Faktor yang Mempengaruhi Produksi Padi Sawah di Desa Sebulu Ilir Kecamatan Sebulu Kabupaten Kutai Kartanegara
}

\author{
(Analysis of Factors Affecting Rice Production in Sebulu Ilir Village \\ Sebulu District Kutai Kartanegara Regency)
}

\author{
Eka Rahmawati ${ }^{1)}$, Agung Enggal Nugroho' ${ }^{2)}$ \& Al Defri ${ }^{3)}$ \\ ${ }^{1)}$ Program Studi Agroteknologi Fakultas Pertanian Universitas Kutai Kartanegara \\ ekarahmawati1316@yahoo.co.id \\ ${ }^{2)}$ Program Studi Agribisnis Fakultas Pertanian Universitas Mulawarman \\ agungenggal@faperta.unmul.ac.id \\ ${ }^{3)}$ Program Studi Agribisnis Fakultas Pertanian Universitas Kutai Kartanegara \\ aldefri@yahoo.com
}

\begin{abstract}
ABSTRAK
Tujuan penelitian ini adalah mengetahui (i) pengaruh tenaga kerja, luas lahan, pupuk dan benih secara simultan maupun parsial terhadap produksi padi sawah di Desa Sebulu Ilir Kecamatan Sebulu, (ii) faktor produksi yang paling berpengaruh terhadap produksi padi sawah secara signifikan dan (iii) permasalahan petani padi sawah di Desa Sebulu Ilir. Penelitian dilaksanakan pada bulan Desember 2018. Mengunakan metode pengambilan sempel secara acak dengan jumlah sampel 32 petani padi sawah. Analisis regresi linear berganda dan uji asumsi klasik digunakan untuk menjawab tujuan penelitian. Hasil penelitian menunjukkan faktor produksi tenaga kerja, luas lahan, dan pupuk NPK secara simultan (bersama-sama) berpengaruh positif dan signifikan terhadap padi sawah. Secara parsial atau sendirisendiri faktor produksi tenaga kerja dan luas lahan berpengaruh terhadap produksi padi sawah sedangkan faktor produksi pupuk NPK tidak berpengaruh terhadap produksi padi sawah. Faktor yang paling berpengaruh terhadap produksi padi sawah adalah tenaga kerja (X1) karena memiliki nilai koefisien sebesar 0,699 dengan nilai T hitung 2,408 dan nilai signifikansi sebesar 0,023. Permasalahan yang dihadapi petani padi sawah di Desa Sebulu Ilir yaitu, irigasi yang belum tertata baik, kurangnya penyuluhan, kurangnya bantuan pemerintah, dan lahan yang berada di wilayah desa lain.
\end{abstract}

Kata kunci: Padi sawah, faktor, produksi, tenaga kerja.

\section{ABSTRACT}

The purpose of this study was to determine (i) the effect of labor, land area, fertilizer and seeds simultaneously or partially on the production of lowland rice in Sebulu Ilir Village Sebulu District, (ii) the factors of production which had the most significant influence on paddy production and (iii) ) problems of rice farmers in Sebulu Ilir Village. The study was conducted in December 2018. Using a random sampling method with a sample of 32 lowland rice farmers. Multiple linear regression analysis and classical assumption tests are used to answer the research objectives. The results showed the factors of labor production, land area, and NPK fertilizer simultaneously (together) had a positive and significant effect on lowland rice. Partially or individually the factors of labor production and land area affect the production of lowland rice while the NPK fertilizer production factor does not affect the production of lowland rice. The most influential factor on lowland rice production is labor (X1) because it has a coefficient value of 0.699 with a calculated $T$ value of 2.408 and a significance value of 0.023 . The problems faced by rice farmers in Sebulu Ilir Village are irrigation which has not been well organized, lack of counseling, lack of government assistance, and land in other village areas.

Keywords: Rice fields, factor, production, labor.

\section{PENDAHULUAN}

Peningkatan produksi beras mengharuskan petani untuk terus menerus menanam padi untuk menjaga keberlanjutan pasokan beras nasional. Produksi padi di Indonesia menemui kendala di bidang produktivitas yang sudah melandai dengan jumlah areal penanaman padi makin menyempit dan kendala pengendalian hama dan penyakit yang disebakan oleh iklim 
mikro yang tercipta di antara pertanaman padi. Dalam hal ini, dibutuhkan teknologi cara penanaman padi yang lebih inovatif yang dapat menambah produktivitas padi sekaligus mengendalikan organisme pengganggu tanaman padi (Kementerian Pertanian, 2015).

Produktifitas tanaman padi sawah di Kabupaten Kutai Kartanegara yang tercatat dari tahun 2015 adalah $51 \mathrm{kw} \cdot \mathrm{ha}^{-1}$ dengan produksi sebesar 173.847 ton, sedangkan produktifitas tanaman padi sawah tahun 2016 dan 2017 tidak tercatat. Pada tahun 2018 produktifitas padi sawah adalah 46,96 kw.ha${ }^{1}$ dengan produksi mencapai 137.196 ha (BPS Kabupaten Kutai Kartanegara, 2019).

Menurut Murdiantoro (2011), usaha padi merupakan mata pencarian dan tulang punggung perekonomian keluarga petani hampir di seluruh Desa di Indonesia. Preses produksi akan berjalan lancar jika 3 persyaratan yang di butuhkan terpenuhi. Persyaratan ini lebih dikenal dengan nama faktor produksi. Usaha tani padi merupakan suatu jenis kegiatan pertanian rakyat yang diusahakan oleh petani dengan mengkombinasikan faktor-faktor produksi seperti alam, tenaga kerja, modal, luas lahan, teknologi, benih dan pengolahan yang di tujukan pada peningkatan produksi.

Masyarakat Desa Sebulu Ilir Kecamatan Sebulu sebagian besar bermata pencarian sebagai petani. Di mana produksi padi yang dilakukan oleh petani di sana menurun dari tahun ketahun. Produksi padi disana juga sangat bergantung pada faktorfaktor produksi yang digunakan. Di mana faktor-faktor produksi tersebut adalah tenaga kerja, luas lahan, pupuk dan benih, Dari daftar kelompok tani Desa Sebulu Ilir Kecamatan Sebulu tahun 2017 ada dua kelompok tani yang berdiri di Desa Sebulu Ilir Kecamatan Sebulu yaitu Panca Karya dan Mekar Jaya, dari data penyuluhan pertanian Sebulu Ilir tahun 2017 terjadi penurunan produksi gabah kering giling sebanyak 30 ton dari 378 ton yang disebabkan luas lahan berkurang dan irigasi yang kurang memadai. Peningkatan hasil produksi sawah dapat tercapai apabila faktor produksi dapat dikelola dengan baik disertai dengan penggunaan dan penerapan teknologi yang moderen. Untuk mendapatkan produksi yang tinggi petani di Desa Sebulu Ilir kecamatan Sebulu tidak hanya memperhatikan luas lahan, tetapi juga perlu memperhatikan banyaknya tenaga kerja dan penggunaan pupuk yang tepat dan seimbang.

Tujuan penelitian ini adalah mengetahui (i) pengaruh tenaga kerja, luas lahan, pupuk dan benih secara simultan maupun parsial terhadap produksi padi sawah di Desa Sebulu Ilir Kecamatan Sebulu, (ii) faktor produksi yang paling berpengaruh terhadap produksi padi sawah secara signifikan dan (iii) permasalahan petani padi sawah di Desa Sebulu Ilir.

\section{METODE PENELITIAN}

Rancangan dalam penelitian ini mengunakan penelitian kuantitatif dimana proses informasi yang didapat disampaikan dalam bentuk angka - angka sebagai alat untuk memberikan keterangan mengenai informasi yang didapat. Alasan dari pengguaan penelitian ini yaitu dalam menjalankan tindakan kepada objek penelitian dengan menggunakan penjelasan tentang variabel penelitian yang digunakan untuk mengukur produksi padi sawah yang didapatkan. Menurut Sugiyono (2015) metode penelitian kuantitatif adalah metode penelitian yang berlandasan pada filsafat positivisme, digunakan untuk meneliti pada populasi atau sampel tertentu, pengumpulan data menggunakan instrumen penelitian, analisis data bersifat kuantitatif/statistik, dengan tujuan menguji hipotesis yang telah ditetapkan.

Penelitian ini dilaksanakan pada bulan Desember 2018. Lokasi penelitian yaitu berada di Desa Sebulu Ilir Kecamatan Sebulu Kabupaten Kutai Kartanegara. Dalam melakukan penelitian ini sumber data yang digunakan terdiri dari data primer dan data sekunder. Teknik pengumpulan data yang digunakan antara lain wawancara,kuisioner, observasi, dokumentasi dan studi kepustakaan. Di Desa Sebulu Ilir Kecamatan Sebulu ada 110 petani karena jumlah populasi lebih dari 100 orang, maka penarikan sampel dalam penelitian ini 
menggunakan sampel secara proporsional random sampling, sedangkan teknik pengambilan sampel menggunakan rumus dari Slovin (Prasetyo \& Jannah, 2008) sebagai berikut :

Dimana :

$$
\mathrm{n}=\frac{N}{1+\left(N \mathrm{e}^{2}\right)}
$$

$\mathrm{n}=$ Jumlah sampel

$\mathrm{N}=$ Jumlah populasi

$\mathrm{e}=$ Persen kelonggaran ketidak telitian karena pengambilan sampel yang masih dapat ditolerir (15\%)

Berdasarkan rumus tersebut maka diperoleh jumlah sampel sebagai berikut :

$$
\mathrm{n}=\frac{N}{1+\left(N \mathrm{e}^{2}\right)} \quad \mathrm{n}=\frac{110}{1+\left(110.0,15^{2}\right)} \quad \mathrm{n}=32
$$

Teknik sampling yang digunakan dalam penelitian ini yaitu simple random sampling Pengambilan sampel secara simple random sampling dilakukan dengan bembuat seperti arisan lalu nama yang keluar dijadikan responden, setiap populasi memiliki kesempatan yang sama untuk dijadikan responden (Arikunto, 2006). Dengan menggunakan teknik simple random sampling didapatkan jumlah sampel sebanyak 32 petani padi sawah di Desa Sebulu Ilir. Variabel independen dalam penelitian ini adalah $\mathrm{X}_{1}=$ tenaga kerja (HOK), $\mathrm{X}_{2}=$ luas lahan (Ha), $\mathrm{X}_{3}=$ Pupuk NPK $(\mathrm{Kg})$ dan $\mathrm{X}_{4}=$ benih $(\mathrm{Kg})$. Sedangkan variabel dependen adalah $\mathrm{Y}=$ produksi padi sawah (Ton).

Analisis regresi linier berganda digunakan untuk mengetahui pengaruh atau hubungan secara linier antar dua variabel atau lebih variabel independen dengan satu variabel dependen (Priyatno, 2014). Untuk menunjukkan seberapa jauh pengaruh satu variabel bebas (luas lahan, pupuk, tenaga kerja dan benih) secara individual dalam menerangkan variasi variabel dependen (Produksi) maka digunakan Uji Parsial (Uji T). Uji Bersama-sama (Uji F) dipakai untuk menunjukkan apakah semua variabel bebas (luas lahan, pupuk, tenaga kerja dan benih) yang dimasukkan dalam model mempunyai pengaruh secara bersama-sama terhadap variabel terikat/dependen (produksi). Uji asumsi klasik yang digunakan adalah (i) uji heteroskedastisitas adalah untuk melihat apakah terdapat ketidak samaan varians dari residual satu pengamatan ke pengamatan lain. Model regresi yang baik adalah model regresi yang tidak heterokedastisitas, Heteroskedastisitas digunakan untuk mengetahui adanya penyimpangan dari syarat - syarat asumsi klasik pada regresi linear. (ii) Uji multikolinieritas yang bertujuan untuk melihat ada atau tidaknya korelasi (hubungan) yang tinggi antara variabel (Ghozali, 2013). Untuk pengujian hipotesis ini digunakan program komputer SPSS 20.

\section{HASIL DAN PEMBAHASAN}

\section{Tingkat Pendidikan Responden}

Pendidikan yang dimiliki petani padi sawah (responden) yang ada di Desa Sebulu Ilir dari tidak tamat SD hingga SLTA, yang berjumlah 32 responden dapat kita lihat dari tabel di bawah ini :

Tabel 1. Tingkat pendidikan responden di Desa Sebulu Ilir

\begin{tabular}{cccc}
\hline No & Pendidikan & Jumlah ( Jiwa ) & Presentase (\%) \\
\hline 1 & Tidak tamat SD & 1 & 6,25 \\
2 & SD/sederajat & 14 & 40,62 \\
3 & SLTP/sederajat & 11 & 31,25 \\
4 & SLTA/sederajat & 6 & 21,87 \\
\hline & Jumlah & 32 & 100 \\
\hline
\end{tabular}

Sumber : Data Primer yang diolah, 2018 
Dari data tabel tersebut di atas dapat kita ketahui bahwa pendidikan responden terbanyak adalah SD, dengan jumlah 14 jiwa atau $40,62 \%$, Pendidikan yang dimiliki petani (responden) akan menentukan cara bercocok tanam pada usahatani padi sawah tersebut, misalnya dalam penyerapan perkembangan modernisasi teknologi pertanian (penggunaan alsintan, metode penanaman, pemupukan dan pemeliharaan), cara pengaturan (manajemen) usahataninya sampai pelaksanaan di lapangan.

\section{Usia Responden}

Tabel 2. Usia petani padi sawah di Desa Sebulu Ilir

\begin{tabular}{cccr}
\hline No & Usia (Tahun) & Jumlah ( Jiwa ) & Presentase ( \% ) \\
\hline 1 & $35-39$ & 4 & 9,37 \\
2 & $40-44$ & 5 & 12,50 \\
3 & $45-49$ & 2 & 3,12 \\
4 & $50-54$ & 7 & 25,00 \\
5 & $55-60$ & 8 & 34,37 \\
6 & $61-65$ & 6 & 15,62 \\
\hline & Jumlah & 32 & 100,00 \\
\hline
\end{tabular}

Sumber : Data Primer yang diolah, 2018

Dari tabel di atas dapat kita lihat bahwa usia responden terbanyak adalah 5560 tahun atau $34,37 \%$, berarti jenis tenaga kerja tersebut merupakan penduduk potensial yang dapat bekerja untuk memproduksi barang dan jasa, dan mempengaruhi kualitas pekerjaan tertentu.

\section{Budidaya Tanaman Padi Sawah di Desa Sebulu Ilir}

Ada beberapa tahapan atau kegiatan yang dilakukan petani di Desa Sebulu Ilir Kecamatan Sebulu dalam budidaya tanaman padi sawah yaitu sebagai berikut :

1. Persemaian

Persemaian benih dilakukan 25 hari sebelum masa tanam. Tempat untuk persemaian tidak terlalu jauh dari lahan persemaian menggunakan sistem tugal/asak untuk setiap lubang tanam tidak memiliki ukuran tertentu hanya menggunakan perkiraan/filing, sebelum ditanam benih di rendam selama 24 jam

2. Pengolahan Lahan
Usia responden dalam penelitian ini berkisar 35-64 tahun. Tingkat usia sangat mempengaruhi aktivitas kerja petani, secara tidak langsung mempengaruhi terhadap produksi usaha taninya. Petani yang usianya muda akan mempunyai kemampuan yang besar untuk mengolah usaha taninya dan sebaliknya petani yang memiliki usia lanjut akan berkurang dalam usaha taninya karena keterbatasan tenaga, namun memiliki banyak pengalaman dalam mengelola usaha taninya. Untuk lebih jelas nya dapat dilihat pada Tabel 2. 
pestisida apa bila hama terlihat banyak menyerang tanaman padi.

5. Panen

Panen dilakukan ketika bulir padi hampir keseluruhan telah menguning yang biasanya 33-36 hari setelah padi berbunga. Cara panen petani di Desa Sebulu Ilir menggunakan sabit dengan memotong pangkal batang panen dilakukan serentak dalam satu lahan.

\section{Lahan Usahatani Padi Sawah}

Lahan produksi yang digunakan oleh petani di Desa Sebulu Ilir adalah persawahan dengan luas tanam 0,5 - $1 \mathrm{Ha}$, dengan jumlah 32 responden dan keseluruhan lahan tersebut berstatus milik sendiri. Ada beberapa lahan petani padi sawah di Desa Sebulu Ilir yang masuk di wilayah desa lain yaitu di Desa Segihan. Lahan sering kebanjiran dan kekeringan karena irigasi yang tidak tertata dengan baik, saat musim hujan lahan akan mengalami kebanjiran begitupun sebaliknya apabila musim panas lahan akan mengalami kekeringan sehingga petani tidak biasa melakukan penanaman meskipun bibit sudah siap untuk ditanam.

Petakan lahan sawah tidak memiliki ukuran tertentu ada yang berukuran besar dan ada yang berukuran kecil. Untuk pengolahan lahan biasanya petani disana menggunakan traktor sawah mareka tidak menyewa traktor sawah karena traktor sawah tersebut adalah bantuan dari pemerintah akan tetapi mareka membelikan bahan bakar untuk traktor sawah dan menggunakan jasa yang ahli menggunakan traktor sawah dengan sistem harian biasanya di upah Rp 100.000,-Perhari. Ada juga beberapa responden yang bisa menggunakan traktor sawah sendiri tanpa menyewa tenaga kerja lain, karena traktor sawah yang ada di Desa Sebulu Ilir hanya ada satu jadi petani disana bergantian menggunkan traktor sawah tersebut dengan jadwal yang sudah ditentukan sebelumnya, biasanya traktor tersebut di gunakan satu sampai dua hari oleh petani tergantung berapa jumlah luas lahan yang dimiliki oleh petani padi sawah di Desa Sebulu Ilir.

\section{Tenaga Kerja}

Tenaga kerja yang digunakan dalam proses produksi terdiri dari tenaga kerja pria dan wanita. Sebagian besar yang digunakan adalah tenaga kerja pria terutama pada saat pengolahan lahan, penanaman, pengaturan air dalam petakan, pengendalian hama dan penyakit tanaman, pemupukan dan panen. Sedangkan tenaga kerja wanita biasanya pada waktu penyulaman, penyiangan, dan panen. Adapun tenaga kerja keluarga yang membantu biasanya pada saat musim tanam dan musim panen dan ada juga beberapa petani yang memakai sistem bergantian membantu petani lain (harian) sistem ini biasanya dilakukan saat musim tanam dan musim panen dan juga sistem gotong royong di Desa Sebulu Ilir masih terjaga biasanya ketua kelompok tani melakukan pengumuman saat ingin melakukan gotong royong seperti perbaikan jalan, irigasi, dan lain lain. Jam kerja dimulai pukul 07:30 04:30 dengan upah rata - rata Rp 100.000,./HOK.

\section{Pupuk NPK}

Sarana produksi berupa pupuk dapat dibeli di kios - kios saprodi pertanian di daerah Sebulu, yang dijual dengan harga $\mathrm{Rp}$ $120.000,-$. Perkarungnya dengan berat $50 \mathrm{~kg}$. Namun terkadang kios yang berada di Desa Sebulu tidak mampu mencukupi kebutuhan yang diperlukan petani sehingga ada yang mencari di daerah Tenggarong yang memerlukan biaya untuk transportasi. Pemberian pupuk NPK tidak memiliki takaran khusus atau dosis yang tepat biasanya dengan luas lahan 1 hektar maupun luas 0,5 hektar tetap digunakan $50 \mathrm{~kg}$ dengan $3 \mathrm{kali}$ pemberian pupuk dan ada petani yang tidak pernah melakukan pengapuran terhadap lahannya dan juga tidak ada variasi pupuk lain seperti pupuk kandang atau pupuk kompos, namun apabila ada bantuan pupuk dari pemerintah barulah petani menggunakan pupuk tersebut itupun tanpa dosis yang tepat.

\section{Benih}

Benih adalah biji yang digunakan untuk melakukan penanaman atau untuk menghasilkan bibit tanaman padi sawah, Di Desa Sebulu Ilir jenis benih yang digunakan adalah padi serang, benih biasa di beli di kios 
- kios pertanian yang ada di Sebulu, bantuan dari pemerintah, dan ada yang menggunakan benih hasil panen sebelumnya.

\section{Uji Asumsi Klasik}

\section{Uji Multikolinieritas}

Cara untuk mengetahui ada atau tidaknya gejala multikolinieritas antara lain dengan melihat nilai Varian Inflation Factor
(VIF) dan Tolerance, apabila nilai VIF kurang dari 10 dan Tolerance lebih dari 0,1 maka dinyatakan tidak terjadi multikolinieritas (Priyatno, 2014).

Setelah dilakukan uji multikolinieritas menggunakan SPSS dengan melihat nilai VIF dan Tolerance maka dinyatakan tidak terjadi multikolinieritas sebagai mana dapat dilihat pada Tabel 3.

Tabel 3. Pengujian Multikolinieritas

\begin{tabular}{lccc}
\hline \multicolumn{1}{c}{ Variabel } & Tolerance & Nilai VIF & Keputusan \\
\hline Tenaga kerja & 0.410 & 2,441 & tidak terjadi multikolinieritas \\
Luas lahan & 0.281 & 3,564 & tidak terjadi multikolinieritas \\
Pupuk NPK & 0.567 & 1,762 & tidak terjadi multikolinieritas \\
Benih & 0.455 & 2,785 & tidak terjadi multikolinieritas
\end{tabular}

Sumber : Data Primer (diolah), 2018.

\section{Uji Heteroskedasitas}

Priyatno (2014), mengatakan bahwa regresi yang baik seharusnya tidak terjadi Heteroskedasitas. Dasar dalam pengambilan keputusan yaitu jika ada pola tertentu, seperti titik yang membentuk pola tertentu yang teratur (bergelombang, melebar,kemudian menyempit), maka terjadi Heteroskedasitas. Jika tidak ada pola jelas, seperti titik-titik menyebar di atas dan di bawah angka 0 dan pada sumbu Y, jadi dapat di simpulkan tidak terjadi Heteroskedasitas.

Berdasarkan hasil pengamatan pengolahan data yang telah dilakukan menggunakan SPSS versi 20 titik yang ada tidak membentuk pola tertentu sehingga dapat disimpulkan bahwa hasil pengujian tahap ini tidak terjadi Heteroskedasitas dan nilai signifikansi koefisien tenaga kerja, luas lahan, pupuk NPK dan benih lebih besar dari 0,05 maka dapat disimpulkan bahwa tidak terjadi Heteroskedasitas.

\section{Analisis Hasil}

\section{Persamaan Regresi Linear Berganda}

Tabel 4. Hasil regresi pengaruh faktor produksi terhadap padi sawah

\begin{tabular}{lclc}
\hline & Variabel & & Koefisien regresi \\
\hline Tenaga kerja & $(\mathrm{X} 1)$ & & 0,699 \\
Luas tanam & $(\mathrm{X} 2)$ & & 0,102 \\
Pupuk NPK & $(\mathrm{X} 3)$ & $-0,026$ \\
Benih & $(\mathrm{X} 4)$ & $\mathrm{F}_{\text {hitung }}$ & 0,929 \\
\hline Konstanta & $=4,138$ & $\mathrm{~F}_{\text {tabel }}$ & $=17,338$ \\
$\mathrm{R}$ & $=0,806$ & Sig & $=2,83$ \\
$\mathrm{R}^{2}$ & $=0,650$ & & $=0,000$ \\
\hline
\end{tabular}

Sumber : Data Primer (diolah), 2018

Berdasarkan tabel di atas dirangkum dari hasil print out SPSS maka diperoleh persamaan regresi sebagai berikut :

$\mathrm{Y}=4,138+0,699 \mathrm{X}_{1}+0,102 \mathrm{X}_{2}+-0,026+0,929$
Nilai konstanta bernilai positif sebesar 4,138 jika $\mathrm{X}_{1}, \mathrm{X}_{2}, \mathrm{X}_{3}$ dan $\mathrm{X}_{4}$ sama dengan nol hasil produksi padi sawah adalah sebesar 4,138, Artinya apabila tenaga kerja, 
luas lahan, pupuk NPK dan benih tidak dilakukan atau dilaksanakan maka produksi padi sawah akan bernilai 4,138 .

1. Nilai koefisien regresi tenaga kerja $\left(\mathrm{X}_{1}\right)=$ 0,699 yang menunjukan besarnya persentase pengaruh yang diberikan tenaga kerja terhadap produksi padi sawah. Artinya setiap penambahan tenaga kerja $1 \%$ maka produksi padi sawah akan meningkat sebesar $0,699 \%$

2. Nilai koefisien regresi luas lahan $\left(\mathrm{X}_{2}\right)=$ 0,102 yang menunjukan besarnya persentase pengaruh yang diberikan luas lahan terhadap produksi padi sawah. Artinya setiap penambahan luas lahan 1 $\%$ maka produksi padi sawah akan meningkat sebesar $0,102 \%$

3. Nilai koefisien regresi pupuk NPK $\left(X_{3}\right)=$ $-0,026$ yang menunjukan besarnya persentase pengaruh yang diberikan pupuk NPK terhadap produksi padi sawah. Artinya setiap penambahan pupuk NPK $1 \%$ maka produksi padi sawah akan berkurang sebesar $0,026 \%$

4. Nilai koefisien regresi benih $\left(X_{4}\right)=0,929$ yang menunjukan besarnya persentase pengaruh yang diberikan benih terhadap produksi padi sawah. Artinya setiap penambahan luas lahan $1 \%$ maka produksi padi sawah akan meningkat sebesar $0,929 \%$

\section{Pengaruh faktor produksi secara simultan (bersama-sama) terhadap produksi padi sawah}

Hasil F-hitung sebesar 17,338 Lebih besar dari F-tabel 2,83 dengan tingkat signifikan 0,000 pada taraf kepercayaan 95 persen $(0,05)$. Data tersebut menunjukan bahwa faktor produksi tenaga kerja, luas lahan, pupuk NPK dan benih secara simultan (bersama-sama) berpengaruh positif dan signifikan terhadap padi sawah, dikarenakan faktor produksi tenaga kerja, luas lahan, pupuk NPK dan benih terpenuhi dengan baik untuk menunjang produksi padi sawah di Desa Sebulu Ilir. Hal ini sependapat dengan temuan penelitian Rohimah (2017) yang menyatakan bahwa tenaga kerja, luas lahan, dan pupuk berpengaruh signifikan terhadap produksi padi sawah.

\section{Pengaruh faktor produksi secara parsial (sendiri-sendiri) terhadap produksi padi sawah}

Tabel 5. Hasil uji-t faktor produksi terhadap produksi padi sawah

\begin{tabular}{ccccc}
\hline Variabel Bebas & $\begin{array}{c}\text { Koefisien } \\
\text { Regresi }\end{array}$ & $\mathrm{T}_{\text {hitung }}$ & $\mathrm{T}_{\text {tabel }} 5 \%$ & Sig \\
\hline Tenaga Kerja (X1) & 0,699 & 2,408 & 2,048 & 0,023 \\
Luas Lahan (X2) & 0,102 & 2,112 & 2,048 & 0,044 \\
Pupuk NPK(X3) & $-0,026$ & $-0,052$ & 2,048 & 0,959 \\
Benih (X4) & 0,929 & 2,112 & 2,04 & 0,067 \\
\hline
\end{tabular}

Sumber : Data primer (diolah), 2018.

\section{Pengaruh Tenaga Kerja $\left(X_{1}\right)$ Terhadap Produksi Padi Sawah}

Faktor produksi tenaga kerja di peroleh t-hitung sebesar 2,408 tingkat signifikan sebesar 0,023 dan lebih besar dari t-tabel yaitu 2,048 hal ini mengandung makna bahwa faktor produksi tenaga kerja berpengaruh signifikan terhadap produksi padi sawah, dikarenakan petani di Desa Sebulu Ilir menggunakan lebih dari $10 \mathrm{HOK}$ dari penanaman sampai panen untuk menunjang produksi padi sawah di Desa
Sebulu Ilir. Hal ini sependapat dengan temuan penelitian Onibala, et. al., (2017) yang menyatakan bahwa tenaga kerja berpengaruh signifikan terhadap hasil produksi.

\section{Pengaruh Luas Lahan $\left(\mathbf{X}_{2}\right)$ Terhadap Produksi Padi Sawah}

Faktor produksi luas lahan diperoleh t-hitung sebesar 2,112 tingkat signifikan sebesar 0,044 dan lebih besar dari t-tabel yaitu 2,048 hal ini mengandung makna 
bahwa faktor produksi luas lahan berpengaruh signifikan terhadap produksi padi sawah, dikarenakan petani di Desa Sebulu Ilir memiliki luas lahan yang cukup luas yaitu $0,5-1 \mathrm{Ha}$ dan berstatus milik sendiri sehingga tidak ada biaya yang di keluarkan untuk sewa lahan. Hal ini sependapat dengan temuan penelitian Saputra dan Wardana (2018) yang menyatakan bahwa luas lahan berpengaruh signifikan terhadap hasil produksi.

\section{Pengaruh Pupuk NPK $\left(X_{3}\right)$ Terhadap Produksi Padi Sawah}

Pada dasarnya faktor produksi pupuk berperan sangat penting didalam menentukan hasil produksi, namun kondisi di sini faktor produksi pupuk tidak berpengaruh signifikan terhadap produksi padi sawah, hal ini disebabkan tidak semua petani menggunakan pupuk sesuai dosis hanya melihat dari kondisi tanaman.

Faktor produksi pupuk NPK diperoleh t-hitung sebesar -0,052 tingkat signifikan sebesar 0,959 dan lebih kecil dari t-tabel yaitu 2,048 hal ini mengandung makna bahwa faktor produksi pupuk NPK tidak berpengaruh signifikan terhadap produksi padi sawah. Dikarenakan pemberian pupuk yang tidak sesuai dosis. Hal ini sependapat dengan temuan penelitian Ilham, et. al., (2017) yang menyatakan bahwa pupuk tidak berpengaruh signifikan terhadap hasil produksi.

\section{Pengaruh Benih $\left(\mathbf{X}_{4}\right)$ terhadap Produksi Padi Sawah}

Faktor produksi bemih diperoleh thitung sebesar 2,112 tingkat signifikan sebesar 0,067 dan lebih besar dari t-tabel yaitu 2,048 hal ini mengandung makna bahwa faktor produksi Benih berpengaruh signifikan terhadap produksi padi sawah, dikarenakan benih padi sawah sangat mudah di cari hampir di setiap toko pertanian yang ada di Desa Sebulu Ilir, di tambah lagi bantuan dari pemerintah sehingga petani di Desa Sebulu Ilir tidak pernah kekurangan stok benih. Hal ini sependapat dengan temuan penelitian Saputra dan Wardana (2018) yang menyatakan bahwa benih berpengaruh signifikan terhadap hasil produksi.

\section{Masalah Dalam Budidaya Padi Sawah Di Desa Sebulu Ilir}

Didalam budidaya tanaman padi sawah di Desa Sebulu Ilir Kecamatan Sebulu ada beberapa kendala dan masalah yang di hadapi petani di Desa Sebulu ilir adalah sebagai berikut :

1. Irigasi adalah usaha penyediaan dan pengaturan air untuk menjaga kestabilan air dalam petakan usaha tani padi sawah. Irigasi yang ada di Desa Sebulu Ilir bisa dikatakan kurang baik karena masih berupa tanah biasa ( belum di semenisasi) dan berukuran kecil, sehingga apabila hujan deras irigasi tersebut tidak bisa menampung air sehingga lahan yang ada kebanjiran dan tidak bias ditanami adapun beberapa kasus petani memanen padi sawah saat banjir menggunakan perahu. Begitupun sebaliknya apabila musim panas lahan akan mengalami kekeringan sehingga bibit yang sudah siap tidak bias ditanam.

2. Teknologi pertanian yang kurang, teknologi pertanian adalah penerapan dari ilmu - ilmu terapan dan teknik pada kegiatan pertanian. Di Desa Sebulu Ilir teknologi pertanian sangat kurang dikarenakan kurangnya penyuluhan oleh pihak terkait dan juga banyak petani yang tidak mengikuti presedur dalam usaha tani padi sawah seperti pemberian pupuk yang sesuai dosis, dan penyuluh lapangan tidak mau mempraktekan secara langsung bagaimana cara budidaya usaha tani padi sawah tidak hanya melalui teori.

3. Bantuan pemerintah yang kurang, bantuan pemerintah sangat penting untuk menunjang produksi padi sawah. Bantuan pemerintah di Desa Sebulu Ilir di bidang pertanian sangat kurang selama ini hanya ada satu hand tractor yang di dapat dari bantuan pemerintah begitupun dengan bantuan seperti bibit,pupuk dan lain - lain sangat jarang diberikan oleh pemerintah.

4. Lahan yang berada di wilayah desa lain, di desa sebulu ilir kecamatan sebulu ada beberapa lahan petani yang berada di 
wilayah desa lain yaitu desa segihan, ini adalah salah satu permesalahan mengapa petani Di Desa Sebulu Ilir sulit mendapat bantuan karena saat membuat sebuah proposal permohonan bantuan kepada pemerintah pihak desa ( kepala desa) tidak berani memberikan tanda tangan baik kepala Desa Sebulu Ilir maupun Desa Segihan. Dikarnakan data penduduk dan data lahan yang berbeda petani bertempat tinggal Di Sebulu Ilir dan lahan pertanian berada Di Desa Segihan . Sampai saat ini masalah ini belum terselesaikan.

\section{KESIMPULAN}

Faktor produksi tenaga kerja, luas lahan, dan pupuk NPK secara simultan (bersama-sama) berpengaruh positif dan signifikan terhadap padi sawah. Secara parsial atau sendiri - sendiri faktor produksi tenaga kerja dan luas lahan berpengaruh terhadap produksi padi sawah sedangkan faktor produksi pupuk NPK tidak berpengaruh terhadap produksi padi sawah. Faktor yang paling berpengaruh terhadap produksi padi sawah adalah tenaga kerja (X1) karena memiliki nilai koefisien sebesar 0,699 dengan nilai $\mathrm{T}_{\text {hitung }} 2,408$ dan nilai signifikansi sebesar 0,023. Permasalahan yang dihadapi petani padi sawah di Desa Sebulu Ilir yaitu, irigasi yang belum tertata baik, kurangnya penyuluhan, kurangnya bantuan pemerintah, dan lahan yang berada di wilayah desa lain.

\section{DAFTAR PUSTAKA}

Akbar, I., Budiraharjo, $\mathrm{K}$ dan Mukson. (2017). Analisis faktor-faktor yang mempengaruhi produktivitas padi di Kecamatan Kesesi, Kabupaten Pekalongan. Agrosocioecomics 1(2).

Arikunto. (2006). Prosedur Penelitian Suatu Pendekatan Praktek. PT. Rineka Cipta. Jakarta.

BPS Kabupaten Kutai Kartanegara. (2019). Kabupaten Kutai Kartanegara
Dalam Angka Tahun 2019. Badan Pusat Statistik Kabupaten kutai Kartanegara. Tenggarong.

Ghozali, I. (2013). Aplikasi Analisis Multivriate dengan Program SPSS. Badan Penerbit Universitas Dipenogoro. Semarang

Kementerian Pertanian. (2015). Rencana Strategis Kementerian Pertanian Tahun 2015 - 2019. Sekretariat Jenderal Biro Perencanaan, Jakarta.

Murdiantoro, B. (2011). Faktor-faktor yang mempengaruhi produksi padi di Desa Pulorejo Kecamatan Winong Kabupaten Pati. Skripsi Fakultas Pertanian Universitas Negeri Semarang.

Onibala, A.G., Sondakh, M.L., Kaunang, R. \& Mandei, J. (2017). Analisis faktor-faktor yang mempengaruhi produksi padi sawah di Kelurahan Koya, Kecamatan Tondano Selatan. Agri-Sosio, 13(2A), 237-242. Retrieved from https://doi.org/10.35791/agrsosek.13. 2A.2017.17015

Prasetyo, B. dan Jannah, L.M. (2005). Metode Penelitian Kuantitatif dan Aplikasi. PT Raja Grafindo Persada. Jakarta.

Priyatno, D. (2014). SPSS Pengolahan Data Terpraktis. Yogyakarta: Andi Offset

Rohimah, U. (2017). Faktor-faktor yang mempengaruhi produksi padi sawah pada lahan sawah bukaan baru (Oryza sativa L.) (Studi Kasus Desa Sindangasih Kec. Cikatomas Kab. Tasikmalaya - Jawa Barat. Jurnal Ilmiah Agritas, 1(2).

Saputra, I.N.A.F \& Wardana, I.G. (2018). Pengaruh luas lahan, alokasi waktu dan produksi petani terhadap pendapatan. E-Jurnal EP Unud, 7 (9). 